\title{
A stunning new species of Jamides Hübner, 1819 (Lepidoptera, Lycaenidae), with notes on sympatric congeners from the Bismarck Archipelago, Papua New Guinea
}

\author{
Chris J. Müller' \\ I Honorary Associate, Australian Museum, 6 College Street, Sydney, NSW 20102 Address for correspondence: \\ PO Box 3228, Dural, NSW 2158 \\ Corresponding author: Chris J. Müller (chrismuller999@gmail.com) \\ Academic editor: M. Nuss | Received 30 November 2015 | Accepted 11 February 2016 | Published 7 March 2016 \\ http://zoobank.org/5A20C9B6-EB95-4688-9792-C33000269650 \\ Citation: Müller CJ (2016) A stunning new species of Jamides Hübner, 1819 (Lepidoptera, Lycaenidae), with notes \\ on sympatric congeners from the Bismarck Archipelago, Papua New Guinea. ZooKeys 571: 113-131. doi: 10.3897/ \\ zookeys. 571.7356
}

\begin{abstract}
Jamides vasilia sp. n., from montane West New Britain Province, Papua New Guinea, is described and illustrated. The new species is strongly divergent from other known Jamides Hübner, 1819 in possessing a high antenna-forewing length ratio, long androconia on the hindwing upperside and a strongly convex forewing inner margin in the male. It is compared by external structures, male genitalia and mtDNA sequence data to putative related species in the cyta group of Jamides. Notes on various Jamides taxa from the Bismarck Archipelago are also provided, with J. pseudosias (Rothschild, 1915) and J. reverdini (Fruhstorfer, 1915) recorded from New Britain for the first time.
\end{abstract}

\section{Keywords}

Taxonomy, Lepidoptera, Lycaenidae, Polyommatinae, new species, Bismarck Archipelago, androconia

Copyright Chris J. Müller. This is an open access article distributed under the terms of the Creative Commons Attribution License (CC BY 4.0), which permits unrestricted use, distribution, and reproduction in any medium, provided the original author and source are credited. 


\section{Introduction}

Jamides Hübner, 1819, butterflies, commonly known as Caeruleans, belong to the subfamily Polyommatinae. The genus is distributed throughout much of the Oriental, Australian and Pacific region tropics (Rawlins et al. 2014) and comprises approximately 60 described species, with a concentration in South East Asia and New Guinea. (Hirowatari 1992) recognised 57 species and additional species have been described by Tennent and Rawlins (2012), and Takanami (1994). From approximately west to east, Kunte et al. (2015), Corbet and Pendlebury (1993), Treadaway and Schröder (2012), Rawlins et al. (2014), Parsons (1998), Tennent (2002) and Tennent (2006) identified six species for India, 16 for the Malay Peninsula, 16 for the Philippines, 21 for Maluku, 15 for Papua New Guinea, eight for the Solomon Islands and nine for the remainder of the South West Pacific, respectively.

Hirowatari (1992) proposed two groups and eight subgroups for Jamides. He noted that, together with members of the genus Nacaduba Moore, 1881, there is exceptional diversity of the male genitalia valva and their morphology is useful in placing species and making phylogenetic inferences about the group.

The new species introduced herein is exceptionally distinct from all other Jamides species. A number of other phenotypically distinct butterflies have recently been recorded from West New Britain Province (Müller 2013, 2014; Müller and Wills 2013), the type locality of the new species.

\section{Materials and methods}

Examination of type and other relevant material was carried out in various institutions (as listed below). Adult specimens were photographed using a Nikon D300s Digital SLR Camera with a Nikon AF-S VR Micro-Nikkor $105 \mathrm{~mm}$ f/2.8G IFED Macro lens and Nikon R1C1 Close-up Kit Flashes Speedlights. RAW images were edited using Adobe Photoshop CS6. Editing included alignment, auto contrasting and removal of background. A standardised procedure was followed with photography and image editing to ensure consistency of image output. Genitalia were extracted following maceration of abdomens in $10 \% \mathrm{KOH}$ at room temperature for 36 hours. Genitalia were photographed in glycerol using the fore-mentioned camera body adapted to a Meiji Techno EMZ-5TR-P-FOI Trinocular Stereozoom Microscope, with OPTEK FL95E Fibreoptic Illuminator and twin arm optical fibre. Individual images were taken with the remote acquisition software DIYPhotoBits Camera Control 5.2. Sliced genitalia photographs were stacked and concatenated using the software Helicon Focus 6.0 and edited in Adobe Photoshop CS6. The plates were assembled in Adobe InDesign CS6 and the phylogeny tree in CorelDRAW X6. Genitalia were stored in small glycerolfilled vials pinned beneath the specimen.

Descriptions of external facies follow that of the numerical vein system of Corbet and Pendlebury (1993). Nomenclature of genitalic descriptions follows the same reference. 
Tissue material (two legs) was collected from representatives of all of the eight $J a$ mides subgroups of Hirowatari (1992), except that of the monotypic celebica Eliot, 1969 group, originally ascribed to Epimastidia Druce, 1891. Genomic DNA was extracted using the Qiagen DNEasy extraction kit, following the guided protocol by the manufacturer. Nucleotide sequence alignment was done by eye using Bioedit. For COI, a 654 bp fragment was amplified using Folmer et al. (1994) LCO (5'-GGTCAACAAATCATAAAGATATTGG-3') and HCO (5'-TAAACTTCAGGGTGACCAAAAAATCA-3').

Individual sequence properties were assessed using MEGA, version 4.1 (Tamura et al. 2006). Bayesian analyses of the dataset were carried out using MrBayes, version $3.0 \mathrm{~b} 4$ (Ronquist and Huelsenbeck 2003). Three independent Bayesian runs at temperature settings in the range $0.2-0.4$ were performed on the data using metropolis coupled Markov chain Monte Carlo simulations, from one to 5 million generations each, and tree sampling every 100 generations. Bayesian topology and branch posterior probabilities were computed by majority rule consensus after deleting the first 1000 000 generations (10 000 trees) as 'burn-in', after confirming that likelihood values had stabilized prior to the 100 000th generation.

Sequences were uploaded to GenBank (http://www.ncbi.nlm.nih.gov/genbank/) and are listed for each individual in the phylogenetic tree presented in Fig. 59. Additional sequences of Jamides taxa (also listed in the tree) were downloaded from Genbank and manually aligned with the dataset. Where possible, the species identity of the latter sequences was checked through the BOLD online database image gallery (http:// www.boldsystems.org/).

\section{Abbreviations}

AM Australian Museum, Sydney, Australia.

CJMC Reference collection of Chris J. Müller, Sydney, Australia.

MNHU Museum für Naturkunde der Humboldt-Universität, Berlin, Germany.

NARI National Agricultural Research Institute, Boroko, Port Moresby, Papua New Guinea.

NHM Natural History Museum, London, England.

SMT Staatliches Museum für Tierkunde, Dresden, Germany.

\section{Taxonomy}

Jamides vasilia Müller, sp. $\mathbf{n}$.

http://zoobank.org/2FF4EC45-5602-4583-BF61-424613106C50

Figs 1-9, 46, 53

Type material. Holotype $\widehat{\partial}$ (Figs 1-3): Papua New Guinea, Whiteman Range, West New Britain Province, 1050m, 559'S, 150³5'E, 19 Nov, 2013, Chris J. Müller, geni- 

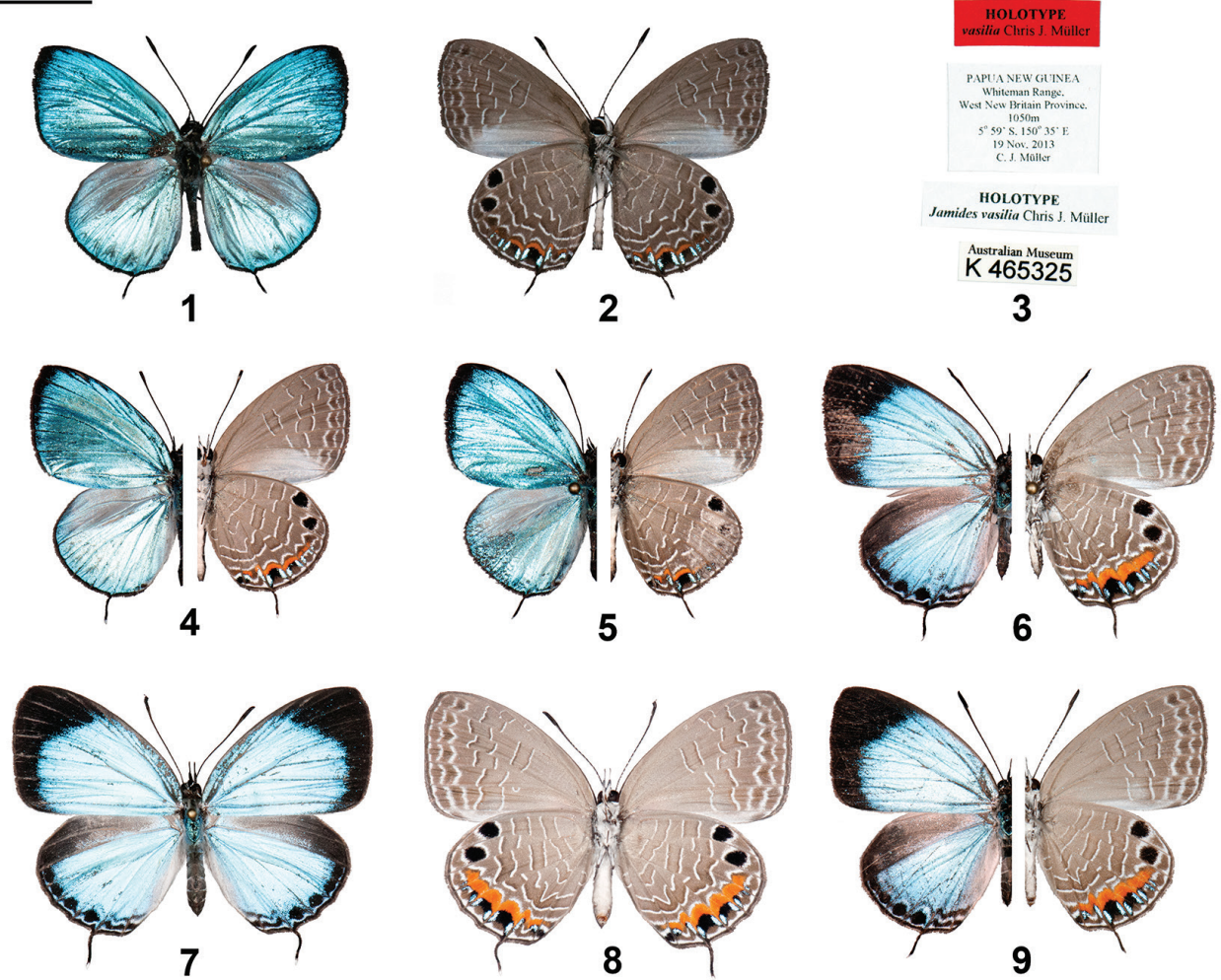

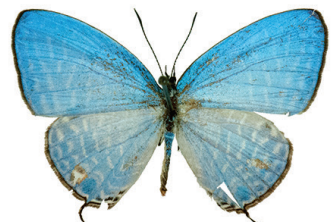

10

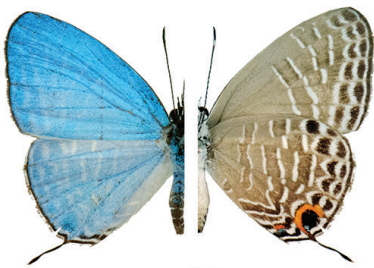

13

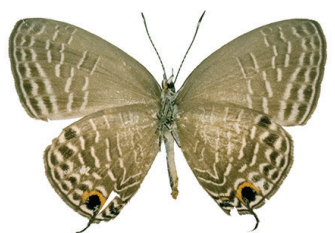

11

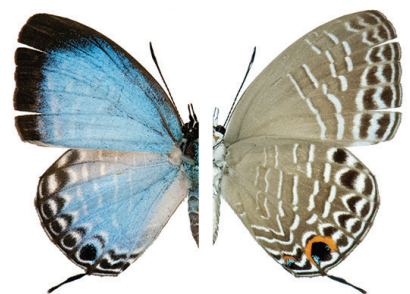

14

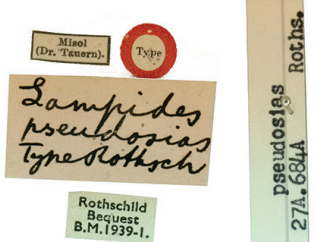

12

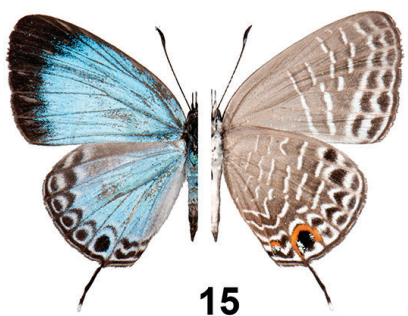

Figures I-I5. Jamides adults (left side upperside and right side underside, where halved) and label data. I Jamides vasilia holotype $\widehat{\partial}$ upperside $\mathbf{2}$ J. vasilia holotype $\widehat{\partial}$ underside $\mathbf{3} \mathrm{J}$. vasilia holotype $\widehat{\partial}$ label data $4 \mathrm{~J}$. vasilia paratype $\delta$ (halved) $5 \mathrm{~J}$. vasilia paratype $\widehat{\partial}$ (halved) (note rubbed hindwing) $\mathbf{6} \mathrm{J}$. vasilia paratype + (halved) (note rubbed forewing) $\mathbf{7} \mathrm{J}$. vasilia paratype $q$ upperside $8 \mathrm{~J}$. vasilia paratype $q$ underside $9 \mathrm{~J}$. vasilia paratype $q$ (halved) $10 \mathrm{~J}$. pseudosias holotype $\widehat{\partial}$ upperside II J. pseudosias holotype $\widehat{\partial}$ underside $\mathbf{I} \mathbf{~ J}$. pseudosias holotype $\widehat{\partial}$ label data $\mathbf{1 3} \mathrm{J}$. pseudosias $\partial \hat{~(h a l v e d) ~(N e w ~ I r e l a n d) ~} 1 \mathbf{4} \mathrm{J}$. pseudosias ㅇ (halved) (New Ireland) 15 J.p pseudosias $q$ (halved) (New Britain). Scale bar $=10 \mathrm{~mm}$. 
talia dissected and held in vial pinned to specimen (AM), Registration: AM K.465325. Paratypes (3 $\widehat{\jmath}, 5$ 우우): 1 labelled as holotype but dated 10 Nov, 2014 (NHM); 1 đ labelled as holotype but dated 26 Nov, 2014 (CJMC); 1 ô labelled as holotype but dated 22 Nov, 2014, Chris J. Müller (CJMC); 1 P labelled as holotype but dated 10 Nov, 2014 (AM), Registration: AM K.465326.; 1 q labelled as holotype but dated 13 Nov, 2014 (NHM); 1 q labelled as holotype but dated 07 Dec, 2014 (CJMC); 1 o labelled as holotype but dated 19 Apr, 2013 (CJMC); 1 o labelled as holotype but dated 07 Nov, 2014 (NARI).

Diagnosis. Both sexes of Jamides vasilia are highly distinctive and cannot be confused with any other known species. The uppersides of both sexes are brighter and more reflective than those of other species in the genus, the ground colour of the male in particular rivalling Morpho butterflies in intensity and radiance. The male of J. vasilia is unusual from a structural perspective, having long antenna (versus forewing length) that extend well beyond the cell and reach the postmedian area. The antenna/forewing length ratio is $\sim 0.6$, whereas in all other known Jamides species the antenna of the male is approximately half the length of the forewing. The shape of the male forewing is unique in that the tornus and inner margin are rounded, the latter being convex while in all other Jamides species the inner margin is straight. Also peculiar in the male is the large purple-brown patch occupying the costal one-third of the hindwing upperside. This patch is adorned with long androconial hairs (up to $5 \mathrm{~mm}$ in length). No other known Jamides bears such prominent structures. The male forewing upperside bears a thick terminal black border, tapering towards the tornus, not present in other species. On the underside, both sexes are easily recognised by the curved striae that are well displaced between veins on both wings and the two apical black spots on the hindwing are more rounded and pronounced than in other taxa. The area of orange bordered by metallic blue on the hindwing underside is extensive in both sexes, particularly the female, and extends from the inner margin all the way to space 5 . The male forewing underside has the entire median area grey-white between the inner margin and vein 2 .

The male genitalia of J. vasilia is unusual, bearing long teeth-like processes on the inner margin of the valva, with a spine-like process at the apex of the valva.

Description. of Forewing length $15.8 \mathrm{~mm}$ (Holotype), Antenna length $9.5 \mathrm{~mm}$ (Holotype). Head grey; antenna long and extending well beyond end of cell, black ringed with white; thorax blue scaled on upperside, grey beneath; abdomen dark grey with blue scales near base on upperside; legs black with white between segments.

Forewing with tornus rounded (in congeners squared), and inner margin convex (in congeners straight).

Forewing upperside brilliant metallic sky blue, darkening slightly towards termen and apex, a prominent black termen border widening to $-1.5 \mathrm{~mm}$ at apex; cilia black. Forewing underside deep grey-brown; inner margin broadly pale grey-white (in spaces $1 \mathrm{a}$ and $1 \mathrm{~b}$ ), with some metallic sky blue scales along vein $1 \mathrm{~b}$; termen narrowly white; a narrow grey-brown subterminal band, narrowly edged with white that forms triangular marks on basal edge; a postmedian band of similar colour to ground colour, about $2 \mathrm{~mm}$ wide, narrowly edged with curved white on outside margin and with 
corresponding dark brown on inside margin, band is strongly displaced at veins by approximately $1 \mathrm{~mm}$, towards base in spaces 6 and 7 and incrementally towards base towards inner margin in spaces 2, 3 and 4; a median band at end of cell, approximately $1.5 \mathrm{~mm}$ wide, curved and edged with white and dark brown as in postmedian band; cilia dark brown.

Hindwing rounded, with $2.5 \mathrm{~mm}$ long, black tail at vein 2, tipped with white.

Hindwing upperside brilliant metallic sky blue, darkening slightly towards termen; a large purple-brown patch, clothed with long androconia along costa and in median area, occupying much of spaces 6 and 7 as well as part of cell and space 5; termen narrowly black; a series of diffuse black-dusted and indented subterminal spots, as well as two small black spots at tornus near intersection of vein $1 \mathrm{~b}$. Hindwing underside deep grey-brown; inner margin narrowly white, interspersed with black at vein ends; a large black apical spot $(1.5 \mathrm{~mm}$ diameter) in space 6 and another apical spot of similar colour and dimensions in space 7 , both spots rimmed narrowly with white; two large subtornal black spots in spaces 2 (approx. $1 \mathrm{~mm}$ across) and 3 (approx. $0.4 \mathrm{~mm}$ across) and smaller, less regular black spots in spaces $1 \mathrm{~b}$ and 4, each of these spots broadly edged along veins with metallic sky blue and basally with bright orange, and then fine white arcuate lines; an additional arcuate white subterminal line in space 5 linking the subapical and subtornal black spots; a postmedian band similar to that on the forewing underside, curved and strongly displaced at veins; a median band edged with white and dark brown at end of cell; a basal band approximately $1 \mathrm{~mm}$ wide, edged narrowly with white, displaced at either side of cell; cilia dark brown.

o: Forewing length $20.6 \mathrm{~mm}$, antenna length $10.8 \mathrm{~mm}$, antenna, thorax, abdomen and legs similar to male.

Forewing with inner margin straight.

Forewing upperside bright lustrous sky blue, darkening towards termen; apex of termen and apex broadly and sharply edged black $(2.5 \mathrm{~mm}$ and $8 \mathrm{~mm}$ wide, respectively). Forewing underside similar to male, ground colour slightly paler and inner margin only narrowly white-grey and without blue scales, postmedian band extending to vein $1 \mathrm{~b}$, white edging to bands slightly wider and more diffuse.

Hindwing rounded, with black, white-tipped tail at vein 2 (approx. $4 \mathrm{~mm}$ long).

Hindwing upperside bright lustrous sky blue, darkening towards termen; inner margin broadly black, basally transitional to brown, with narrow blue scaling along edge of space 6 and 7 adjacent to cell; a row of black subterminal spots (each averaging $0.6 \mathrm{~mm}$ diameter) in spaces 2, 3, 4 and 5; two irregular black subtornal lines in spaces $1 \mathrm{a}$ and $1 \mathrm{~b}$, subparallel to termen; inner margin narrowly white. Hindwing underside similar to male, ground colour slightly paler, orange bordering subterminal spots wider and very extensive, reaching from the inner margin to space 5.

Male genitalia. Vinculum and tegumen ring broadly oval; sociuncus divergent; socii with lateral margin rounded, socii distinctly separated by straight, perpendicular sinus; saccus of even thickness, brachium widely bowed dorsally, yet sharply bent laterally, tapered dorsally; valva elaborate, hollowed, with serrated margin and teeth-like processes on inner margin, long narrow process stemming from near base of valva, 
weakly clubbed with pointed ventral surface on club; phallus with prezonal section approximately one tenth the length of postzonal section, slender, with apical rounded pencil-like process.

Etymology. This enigmatic and exquisite new butterfly is named in honour of the author's wife, Vasilia (Vicki) Savvas (Muller). Vicki has always supported the author's obsession in butterfly research, despite the many sacrifices both on and off the field.

Distribution. New Britain Island, Papua New Guinea.

Ecology. Adults of J. vasilia inhabit moss forest and appear to have a more rapid, erratic flight than other members of the genus. Two females were initially observed flying around the base of a Syzygium R.Br. ex Gaertn. (Myrtaceae) sapling and resembled those of the lycaenid Arhopala thamyras (Linnaeus, 1758). The particular Syzygium plant had numerous, highly active, medium-sized brown ants present on the lichencovered trunk but no early stages of Jamides could be located either on the foliage, trunk or in leaf litter surrounding the base of the plant. In the upper parts of the Whiteman Range (Figs 60, 61), J. vasilia flies with several other Jamides taxa, including J. reverdini (Fruhstorfer, 1915), J. pseudosias (Rothschild, 1915), J. cyta (Boisduval, 1832), J. allectus (Grose Smith, 1894), J. soemias Druce, 1891 and J. amarauge Druce, 1891. At lower elevations in the same mountain range, J. celeno (Cramer, 1775), J. aetherialis (Butler, 1884) and J. nemophila (Butler, 1876) are abundant.

Remarks. The phylogeny of Jamides, presented in Fig. 59, comprises representative species from each of Hirowatari's eight subgroups of Jamides, with the exception of the monotypic J. celebica (Eliot, 1969). In the Bayesian phylogeny, J. vasilia is recovered in a deeply diverged clade also comprising J. cyta and J. nitens Joicey \& Talbot, 1916.

There is no significant variation in the type series of $J$. vasilia, with all specimens similar in size and shape. The male exhibits very slight variation in the width of the terminal black border.

The extent of distribution of J. vasilia on New Britain Island is not known. Based on the distribution of other endemic butterfly taxa on the island, it is unlikely to be restricted to the Whiteman Range, although no specimens have been observed during surveying, at a range of altitudes, of the Nakanai and Bainings Mountains, in central and east New Britain, respectively. J. vasilia appears to be a rare species.

\section{Notes on sympatric Jamides taxa in the Bismarck Archipelago}

Jamides cyta (Boisduval, 1832)

Figs 16-30, 47, 48, 55

Catochrysops cyta: Boisduval (1832: 87); TL: New Ireland.

Remarks. The type (?types) of Jamides cyta (Boisduval, 1832) were taken in New Ireland, during the voyage of the Astrolabe through the Indo-Pacific during the period 1826-1829. The Astrolabe, captained by Dumont d'Urville, visited at least three coastal 


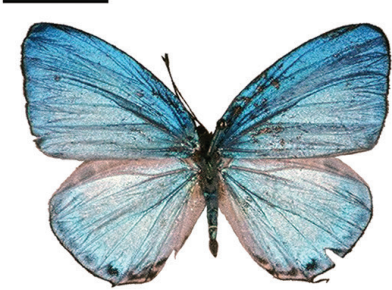

16

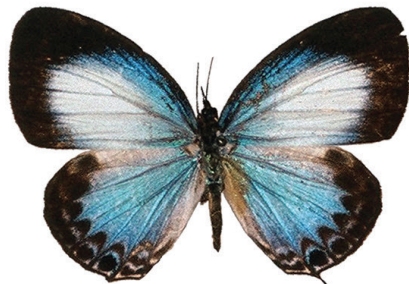

19

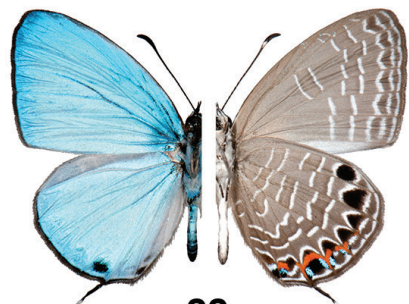

22

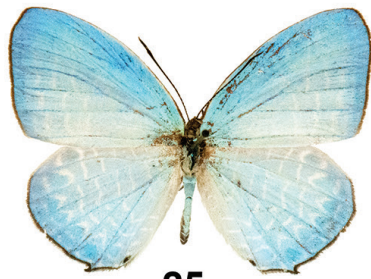

25

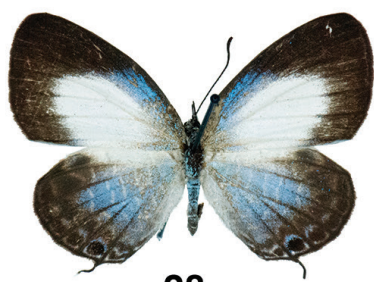

28

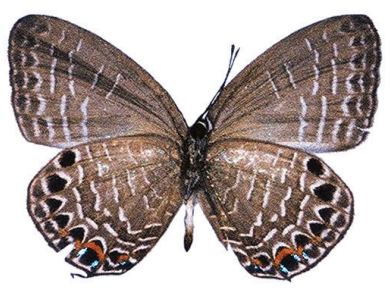

17

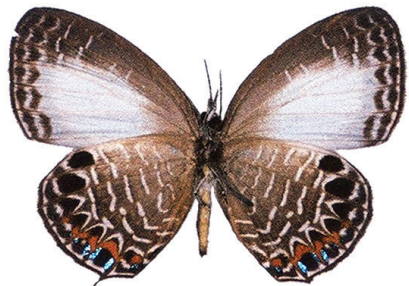

20

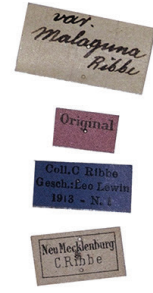

18

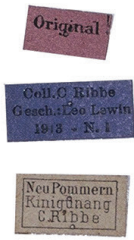

21
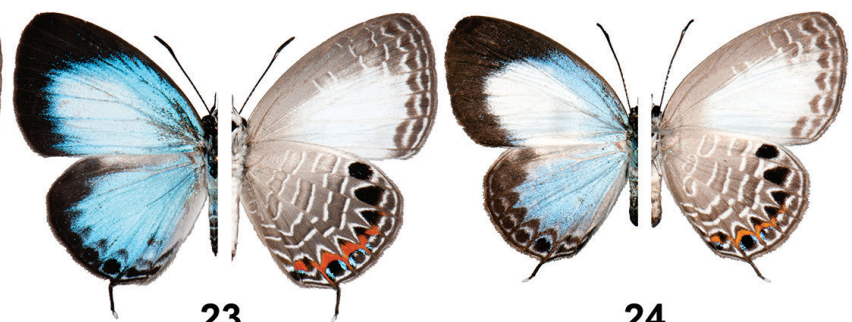

23

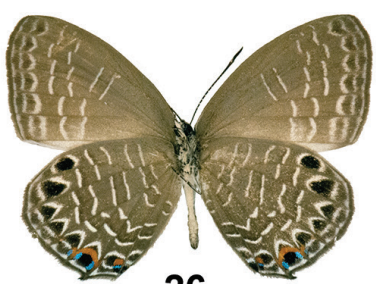

26

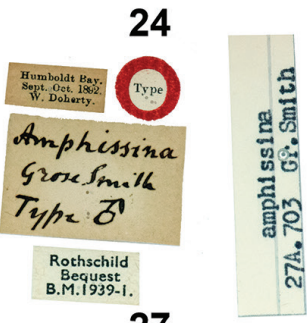

27

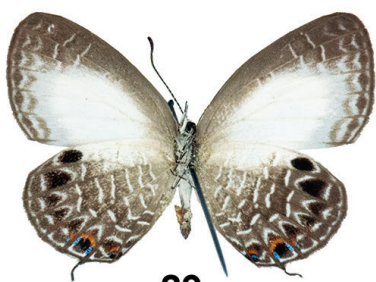

29

Figures 16-30. Jamides cyta adults (left side upperside and right side underside, where halved) and label data. 16 Lampides amphissina var. malaguna lectotype ô upperside 17 As Fig. 16, underside 18 As Fig. 16, label data $19 \mathrm{~L}$. amph. var. malaguna paralectotype $q$ upperside 20 As Fig. 19, underside 21 As Fig. 19, label data 22 J. cyta cyta $\widehat{\jmath}$ (halved) (New Britain) 23 J. c. cyta $\bigcirc$ (halved) (New Britain) 24 J. c. cyta + (halved) (New Ireland) $25 \mathrm{~J}$. c. amphissina holotype $\widehat{\partial}$ upperside $\mathbf{2 6} \mathrm{J}$. c. amphissina holotype $\hat{\sigma}$ underside 27 J. c. amphissina holotype $\bigcirc$ label data 28 J. c. amphissina allotype $q$ upperside 29 J. c. amphissina allotype $q$ underside $30 \mathrm{~J}$. c. amphissina allotype $q$ label data. Scale bar $=10 \mathrm{~mm}$. 
sites in New Ireland; Port Praslin, Hèvre Cartret (Carteret Bay) and Likiliki in the Bay of Frondeurs (=Slinger's Bay) (Domeny de Rienzi 1838). Port Praslin and Carteret Bay are separated by about $15 \mathrm{~km}$ on the western side of New Ireland near the southern tip, in the Cape Saint George Channel. The location of Slinger's Bay is given as "on the N. coast of New Ireland. Lon. 151. E. Lat. 3. S.” by Worcester (1817). The type/s of J. cyta have not been located. However, the description by Boisduval is clear, as follows:

"Ailes d'un bleu-argenté luisant; les inférieures avec une petite queue; dessous des quatre avec plusieurs raies blanches interrompues; les inférieures ayant en outré une rangée marginale de taches noires, don't les trois voisines du bord abdominal marquées de fauve et de vert doré.

Il a le port et la taille d'Elpis, auquel il resemble beaucoup.

Nouvelle-Irlande."

Translated, this states that the insect (presumably a male), has "Wings a shiny silvery blue; the hindwings with a small tail; underside of the four [wings] with several broken white stripes; the hindwings additionally having a marginal band of black spots, of which the three adjacent [closest] to the abdominal [inner] margin are marked with fawn and golden green. It has the appearance and size of Elpis [Jamides elpis (Godart,[1824])], which it closely resembles. New Ireland."

The description above is pertinent only to the male of J. cyta. The author has surveyed several sites throughout New Ireland, close to the localities visited by the Astrolabe, and found J. cyta to be particularly common at all of the lowland sites.

Toxopeus (1930), followed by Riley and Corbet (1938), recognised that cyta was the correct species name to be applied to the species known as Catochrysops amphissa (C. \& R. Felder, 1860). Prior to that time, several subspecies of what are now known to represent J. cyta were described under amphissa, in particular several taxa from Maluku described by Fruhstorfer (1916). J. cyta amphissa is now known to be restricted to northern Maluku (Rawlins et al. 2014).

Ribbe (1899: 228) proposed the name Lycaena amphissina var. malaguna for specimens collected in New Britain, Duke of York Islands and New Ireland. This taxon was considered by D'Abrera (1977: 355) to be a junior synonym of Jamides cyta cyta and Takanami (1989: 50) designated a male lectotype from New Ireland (Neu-Mecklenburg) and recorded three paralectotypes. Both the lectotype and a female paralectotype are here-in illustrated (Figs 16-21).

Nominate cyta from the Bismarck Archipelago is highly distinct from the New Guinea mainland subspecies amphissina Grose Smith, 1894 (not to be confused with amphissa from Maluku), in that the Bismarck specimens are larger and brighter, with much more pronounced orange on the hindwing underside. Bismarck cyta taxa may be further separated in that females from New Britain possess more extensive and brighter blue on the upperside than those from New Ireland and may warrant subspecific status. The types of J. cyta amphissina are illustrated in Figs 25-30 and both sexes of J. cyta cyta from the Bismarcks are also figured (Figs 22-24). 


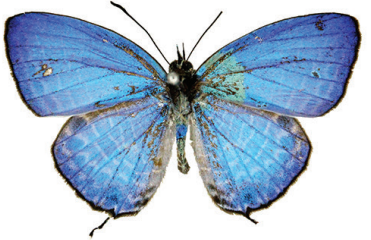

31

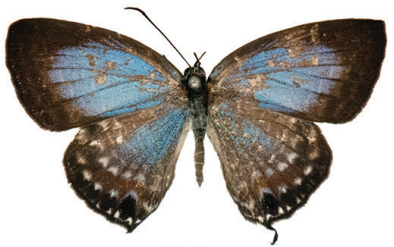

34

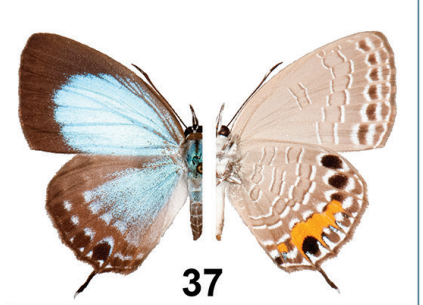

(ripe)

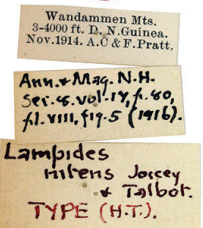

40

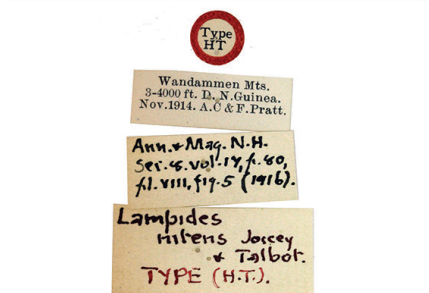

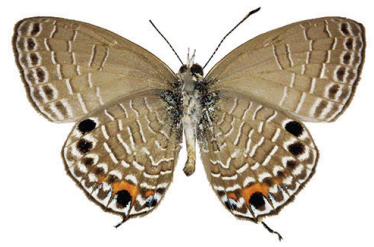

32

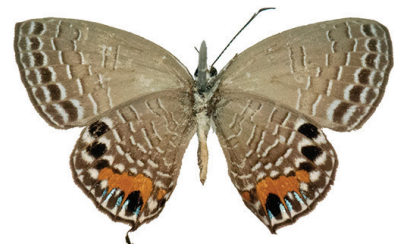

35

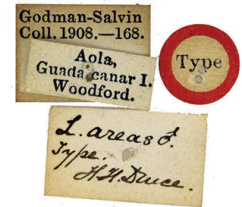

33

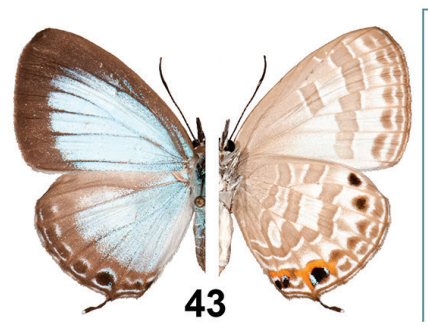

43
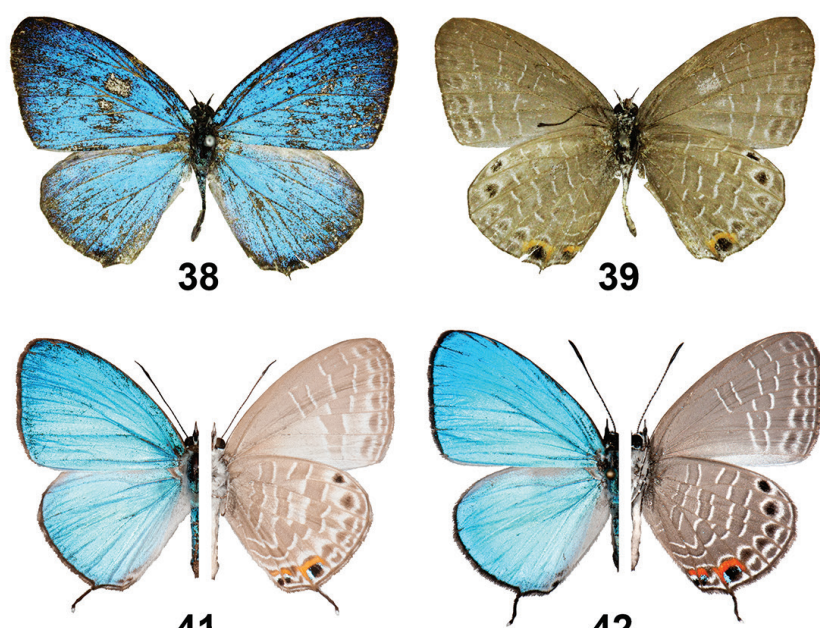

36
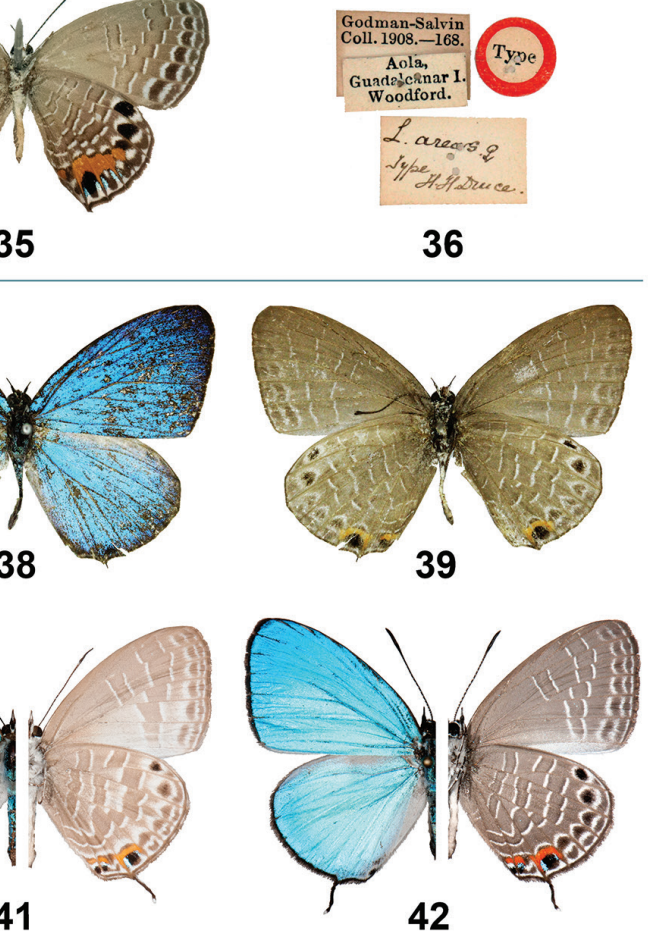

Figures 3 I-45. Jamides adults (left side upperside and right side underside, where halved) and label data. $\mathbf{3}$ I Jamides areas holotype $\delta \hat{~ u p p e r s i d e ~} 32 \mathrm{~J}$. areas holotype $\delta \hat{~ u n d e r s i d e ~} \mathbf{3 3} \mathrm{J}$. areas holotype $\widehat{\delta}$ label data $34 \mathrm{~J}$. areas allotype $q$ upperside $35 \mathrm{~J}$. areas allotype $q$ underside $36 \mathrm{~J}$. areas allotype $q$ label data $37 \mathrm{~J}$. areas + (halved) (Guadalcanal) $38 \mathrm{~J}$. nitens holotype $\delta$ upperside $39 \mathrm{~J}$. nitens holotype $\delta$ underside $40 \mathrm{~J}$. nitens holotype $\widehat{\partial}$ label data $4 \mathrm{I} J$. nitens $\widehat{\partial}$ (halved) (Telefomin) $42 \mathrm{~J}$. nitens $\widehat{\partial}$ (halved) (Mianmin Range) $43 \mathrm{~J}$. nitens $\circ$ (halved) (Telefomin) $44 \mathrm{~J}$. reverdini ${ }^{\wedge}$ (halved) (New Britain) $45 \mathrm{~J}$. reverdini $ᄋ$ (halved) (New Britain). Scale bar $=10 \mathrm{~mm}$. 

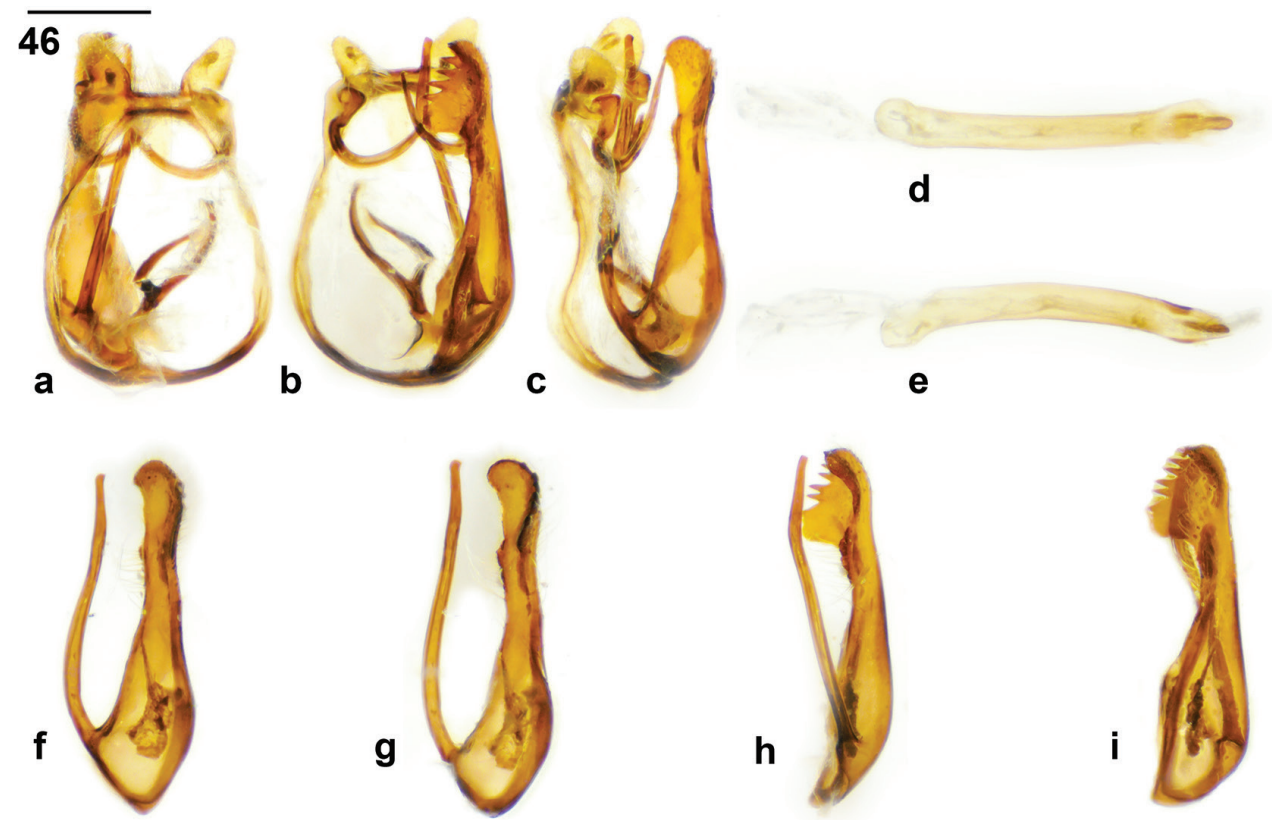

c
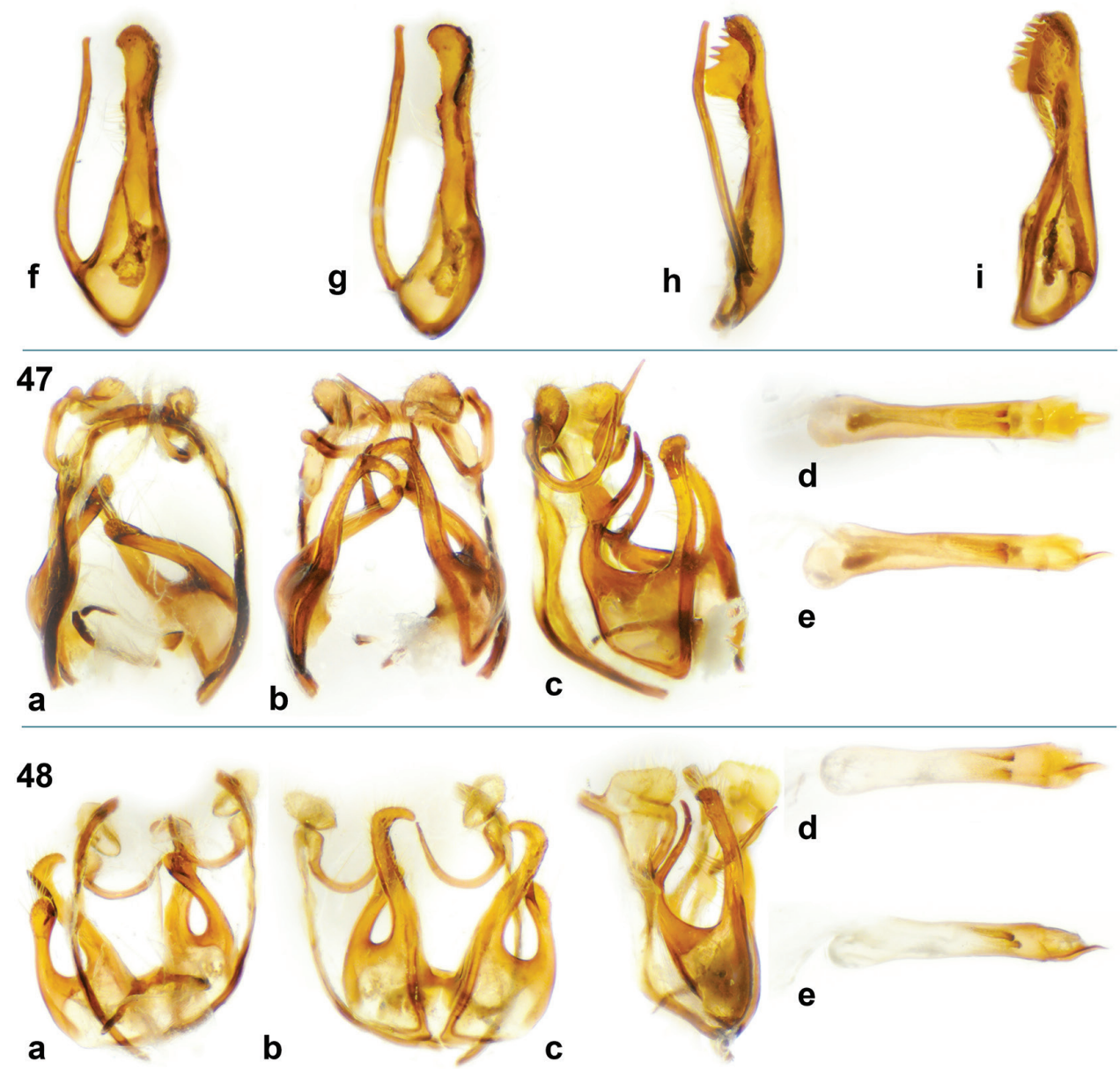

Figures 46-48. Jamides male genitalia. (a genitalia in dorsal view with aedeagus removed, $\mathbf{b}$ genitalia in ventral view with aedeagus removed, $\mathbf{c}$ genitalia in lateral view with aedeagus removed, $\mathbf{d}$ aedeagus in dorsal view, $\mathbf{e}$ aedeagus in lateral view, $\mathbf{f}$ valva in lateral external view, $\mathbf{g}$ valva in lateral interior view, $\mathbf{h}$ valva in dorsal view, $\mathbf{i}$ valva in ventral view. $\mathbf{4 6}$ Jamides vasilia holotype $\mathbf{4} \mathbf{4 7} \mathrm{J}$. cyta cyta (New Britain) $48 \mathrm{~J}$. cyta amphissina (Sepik, mainland NG). Scale bar = approx. $1 \mathrm{~mm}$. 

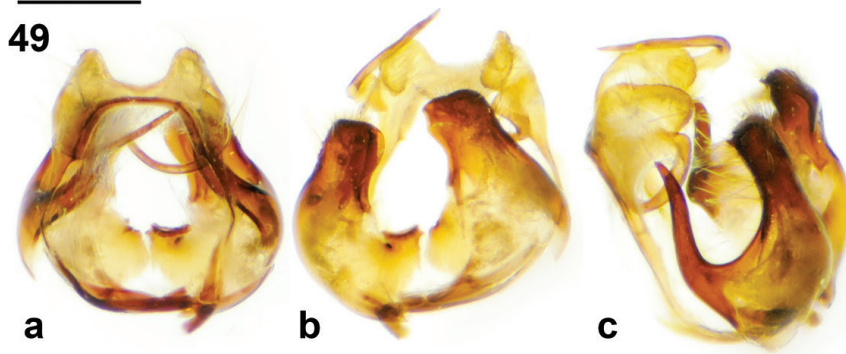

d
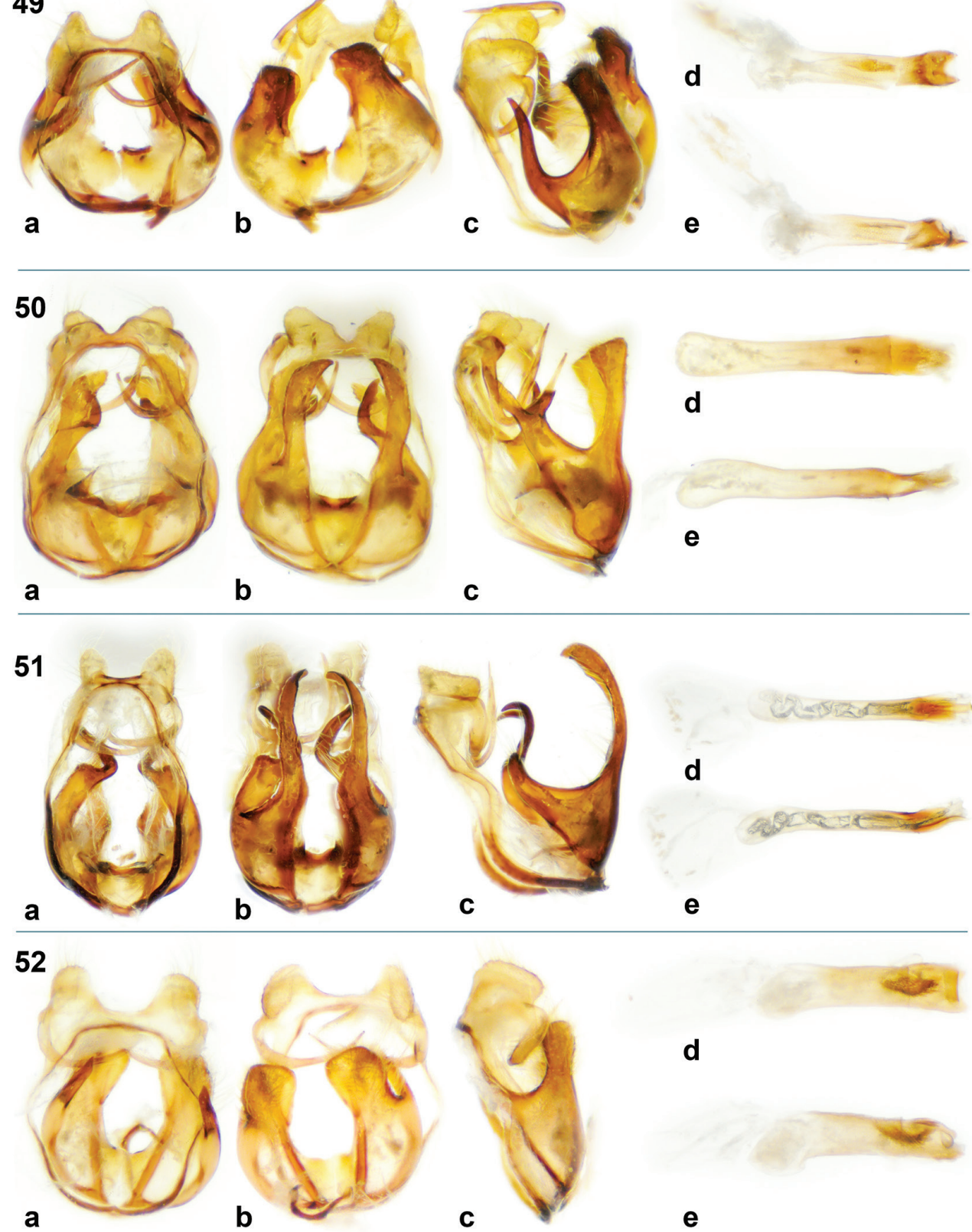

Figures 49-52. Jamides male genitalia. (a genitalia in dorsal view with aedeagus removed, b genitalia in ventral view with aedeagus removed, $\mathbf{c}$ genitalia in lateral view with aedeagus removed, $\mathbf{d}$ aedeagus in dorsal view, e aedeagus in lateral view. 49 J. pseudosias (Mianmin Range) $\mathbf{5 0}$ J. areas (New Georgia, Solomons) $\mathbf{5} \mathbf{I}$ J. nitens (Mianmin Range) $\mathbf{5 2} \mathrm{J}$. reverdini (New Britain). Scale bar = approx. $1 \mathrm{~mm}$. 

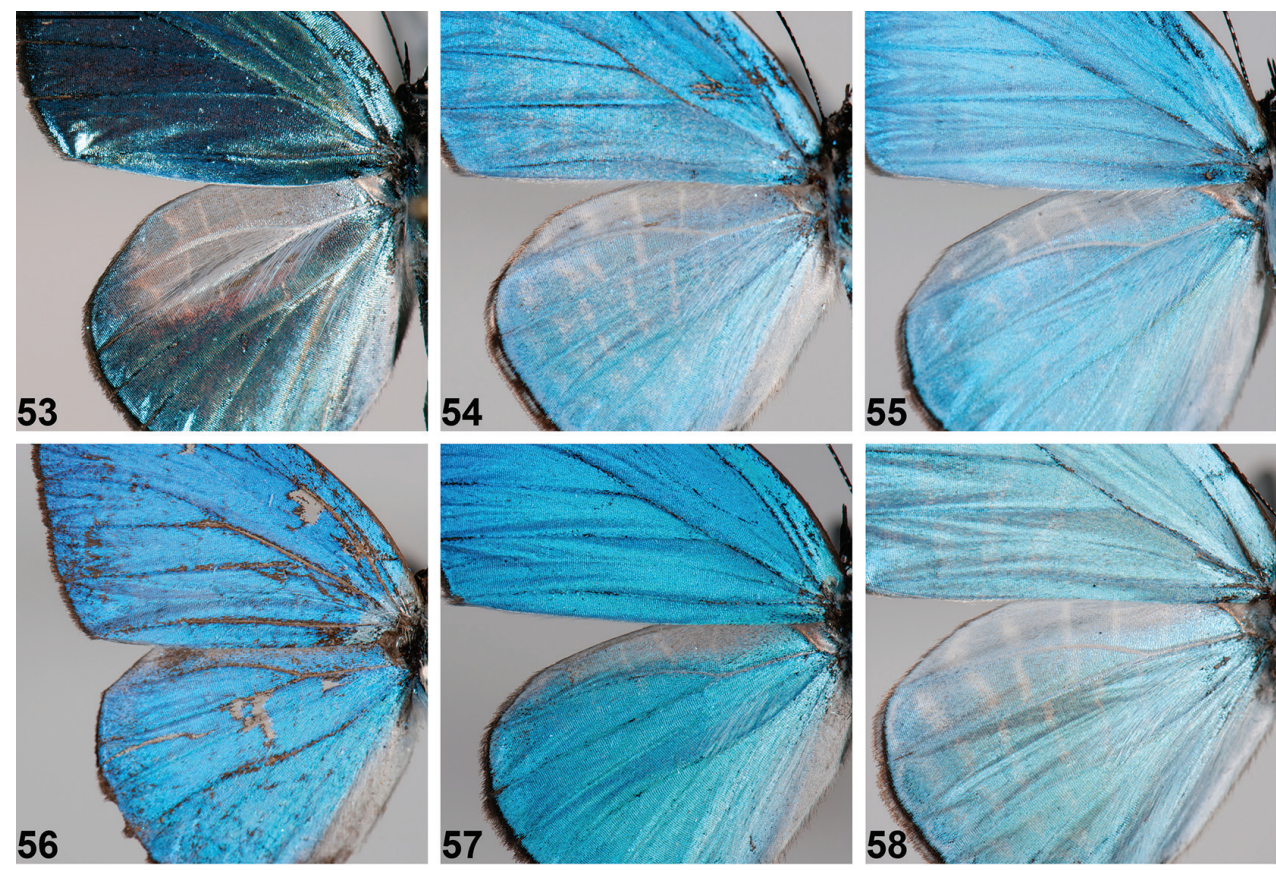

Figures 53-58. Jamides male hindwing apex, showing development (or absence) of androconia. $\mathbf{5 3}$ Jamides vasilia paratype $\widehat{ } 54 \mathrm{~J}$. pseudosias (Mianmin Range) $55 \mathrm{~J}$. cyta cyta (New Britain) 56 J. areas (New Georgia, Solomons) 57 J. nitens (Mianmin Range) 58 J. reverdini (New Britain). Scale bar = approx. $1 \mathrm{~mm}$.

J. cyta is an easily recognised species, the male bearing a pale blue-white upperside and both sexes bear a row of triangular subterminal black spots on the hindwing underside. Note that the illustration of the male J. 'cyta' (as Jamides 'cytus') in Parsons (1998) is in fact that of J. pseudosias.

\section{Jamides pseudosias (Rothschild, 1915)}

Figs 10-15, 49, 54

Lampides pseudosias: Rothschild (1915: 138); TL: Misol [Misool].

Remarks. In the Bismarcks J. pseudosias was known only from one pair taken at an unspecified locality in New Ireland by A. F. Eichhorn in November 1923, which are held in the NHM (Figs 13, 14). A female taken at the type locality of J. vasilia is also figured (Fig 15), representing the first record from New Britain.

$J$. pseudosias is readily distinguished from its congeners by its long hindwing tail, which is at least 1.5 times that of related species in New Guinea and by the rich blue colour of the male upperside. The forewings of the male are narrower and the apex more rounded than in related species. The forewing underside median bar and postmedian 
band are continuous across vein 3 , though slightly oblique, giving the band a curved appearance. Note that Parsons (1998) illustrates a male of this species as that of J. cyta (as J. 'cytus'; see under J. cyta in this work).

\section{Jamides reverdini (Fruhstorfer, 1915)}

Figs 44, 45, 52, 58

Lampides elpis reverdini: Fruhstorfer (1915: 143); TL: ST Holl. Zentral Neu Guinea, Kloofbivak [Papua, Indonesia].

Remarks. Jamides reverdini was previously known from the Bismarcks from just a single specimen from New Ireland, which Parsons (1998) considered to be possibly mislabelled. Additional material is here recorded from close to sea level near Poronbus in New Ireland and from both the Whiteman Range (approximately $1000 \mathrm{~m}$ ) and Bainings Mountains (2000m), in West and East New Britain Provinces, respectively. Therefore, the taxon has a notably extensive vertical range in the Bismarck Archipelago. In northern mainland New Guinea, for example in the Upper Sepik, J. reverdini is most commonly observed below $500 \mathrm{~m}$ (pers. obs.)

This insect is unique in its comparatively large size, bright silvery blue upperside and boldly patterned underside. On the underside, the ground colour is a distinct deep grey and, like $J$. pseudosias, the forewing median bar and postmedian band are connected at vein 3. J. reverdini is easily separated from J. pseudosias by, among other forementioned features, the shape of the subterminal band on the hindwing underside. In J. reverdini, this band constitutes a series of rectangular markings bordered heavily with white, whereas in J. pseudosias these markings are distinctly triangular.

\section{Discussion}

Jamides vasilia exhibits significant disparity from other members of Jamides. The male wing shape, with rounded tornus and convex inner margin, is unique, as is the black, tapering terminal border. On the forewing underside of the male the inner margin is broadly white-grey, relative to the remainder of the wing, a feature apparently unique in the genus. Also in the male, the hindwing upperside bears conspicuous androconia (Fig. 53), covering a purple-brown patch. Such prominent androconia are either absent or poorly developed in related species (Figs 54-58). The underside bands of both sexes are very curved and displaced at veins, unlike other Jamides taxa. J. vasilia is exceptionally bright, the male with the upperside luminescence possibly unmatched in Indo-Pacific Lycaenidae.

The male genitalia of J. vasilia (Fig. 46) are equally distinct and are unlike any of its congeners (Figs 47-52). The exaggerated teeth-like projections of the valva (Figs $46 \mathrm{~h}, 46 \mathrm{i})$ are unique. The dorsal projection of the valva is characteristic of the genus 


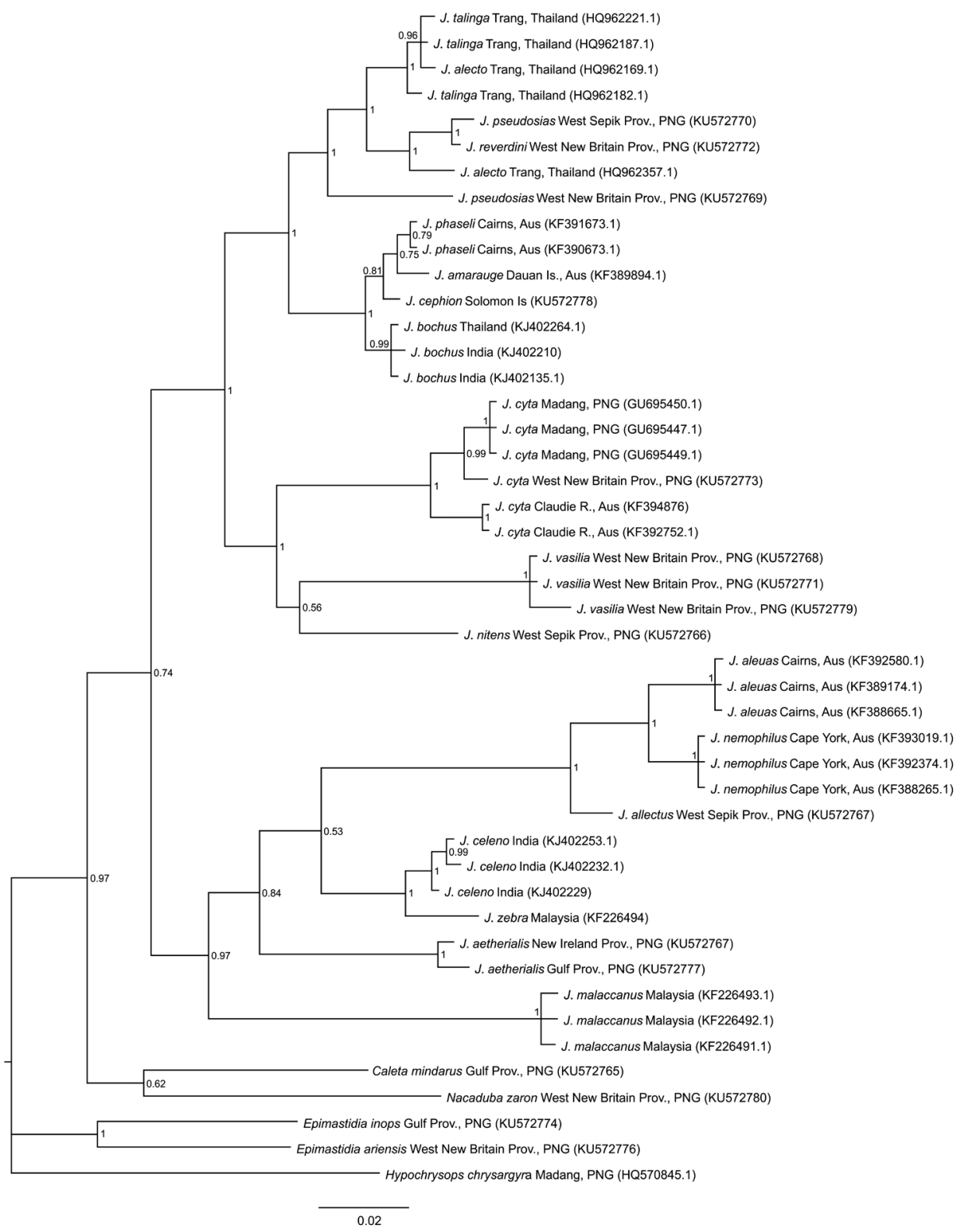

Figure 59. Fifty percent majority rule consensus phylogram for selected Jamides, from a Bayesian analysis of 650 base pairs of COI gene fragment. Numbers at the nodes are the posterior probabilities of those nodes. The scale bar represents $2 \%$ genetic distance. Each terminal indicates the taxon name, locality and Genbank sequence accession number. Note the following abbreviations in parentheses for Province (Prov.), Papua New Guinea (PNG) and Australia (Aus). 


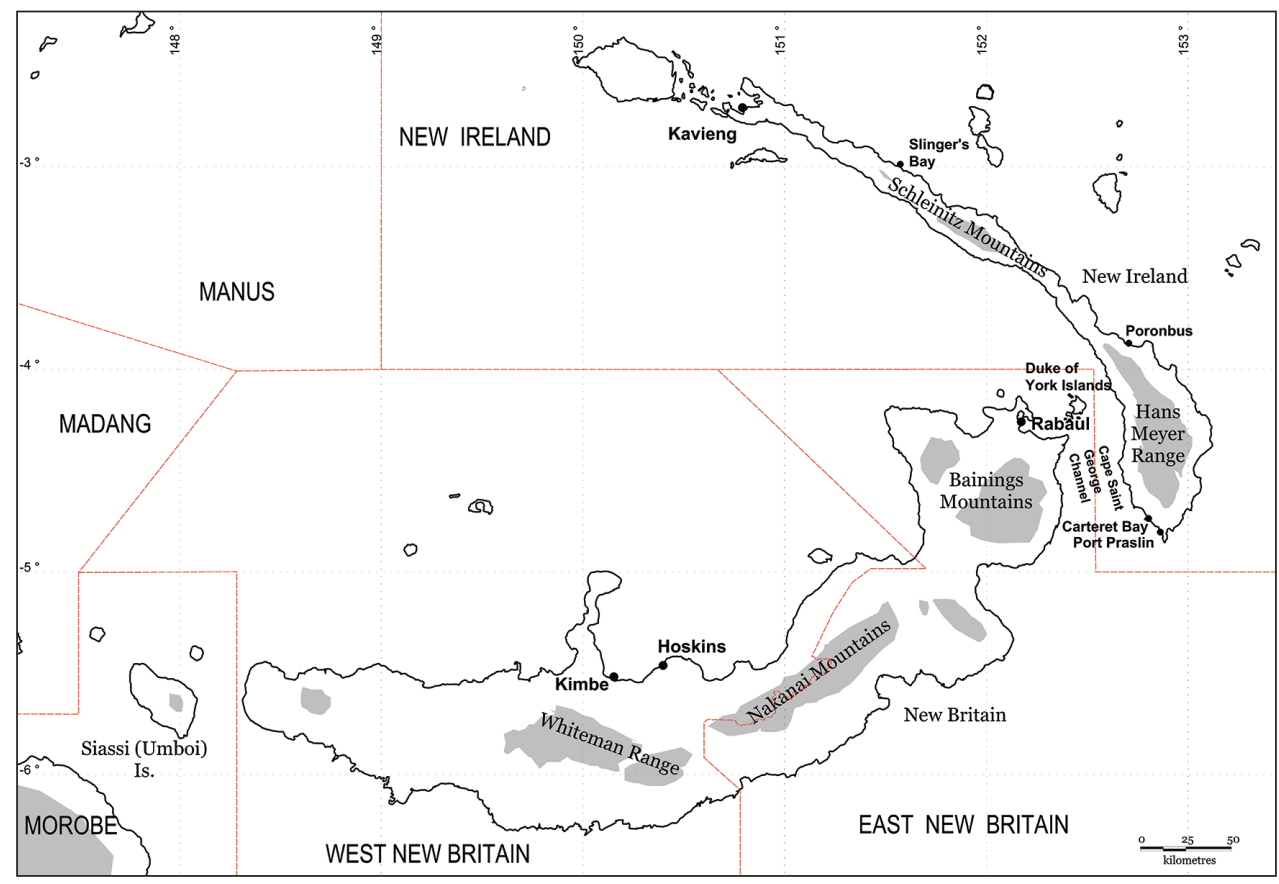

Figure 60. The Bismarck Archipelago, Papua New Guinea, showing all main islands (excluding the Admiralty Group), provinces (upper case), main centres and localities referred to in the text. Shading represents approximate expanse of land above $1000 \mathrm{~m}$ elevation.

Jamides and in Indo-Pacific Polyommatinae appears to be shared only with the genus Callictita Bethune-Baker, 1908.

That $J$. vasilia was phylogenetically recovered, as a result of Bayesian Inference, within a clade of Jamides also comprising J. cyta and J. nitens is perhaps unexpected, considering that $J$. vasilia is phenotypically very different from either of these taxa. Indeed, there is significant genetic divergence (in COI barcode) between J. vasilia and $J$. cyta or J. nitens. However, a potential similarity between J. vasilia and J. cyta is that the latter has been recorded feeding on Syzigium in Australia (Braby 2000) and, based on adult female behaviour (see Remarks section), is possibility the food plant of J. vasilia. J. nitens (Figs 38-43) is one of the, otherwise, brightest Jamides taxa. Parsons (1998) noted that J. nitens exhibits a deeper blue than related species in Papua New Guinea. Although the male upperside rich sky blue appears to be constant in all specimens, both sexes exhibit some degree of variability of the amount of white suffusion bordering the striae on the underside (hence three males of $J$. nitens are figured, see Figs 38-42).

J. vasilia is a montane species, having been recorded from 850 to $1050 \mathrm{~m}$. An additional female was observed at $700 \mathrm{~m}$ in the Whiteman Range. Of the related Jamides taxa, J. nitens is also a montane insect, Parsons (1998) recording it from 1200-1800m, although the author has recorded this species from the Mianmin Range from as low as $550 \mathrm{~m}$. J. cyta is typically a lowland species and is rarely recorded above about $500 \mathrm{~m}$, 


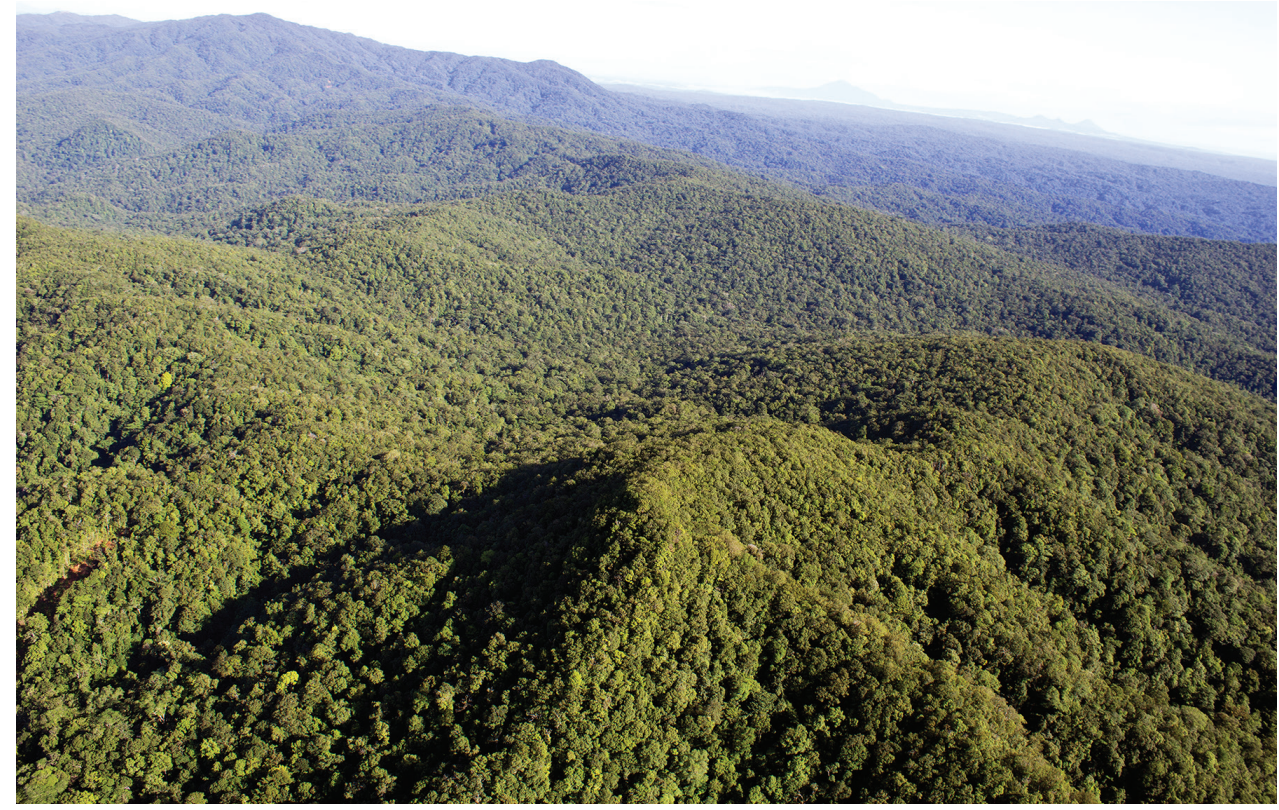

Figure 6I. The Whiteman Range, West New Britain; type locality of Jamides vasilia.

although it has been seen very occasionally up to $900 \mathrm{~m}$ in the Whiteman Range (pers. obs.). Parsons (1998) records J. cyta from sea level to $700 \mathrm{~m}$. J. reverdini and J. pseudosias appear to be predominantly montane in New Britain, the former being seen by the author at over 2,000m in the Bainings Mts, East New Britain Province. However, in mainland New Guinea, both species tend to occur in the lowlands. In the Solomons, J. areas (Figs 31-37) is generally a lowland species and the species was found to be fairly common at Uepi Island, New Georgia Group, at sea level during 1986 (pers. obs.). It is unknown to what extent, if any, vertical elevation separation has played in the role of Jamides diversification in the New Guinea region.

Various phylogenetic analyses produced a range of trees for the Jamides dataset. Indeed, in several, including Neighbour-Joining, Maximum Likelihood and Maximum Parsimony, the resultant tree suggested that J. vasilia is sister to all assessed Jamides species groups and that it may represent a separate genus. Given the variable results from the different methods, COI alone is clearly not an adequate tool and additional sequencing of nuclear gene fragments would undoubtedly assist in better resolving the phylogenetic position of the new taxon.

\section{Acknowledgements}

A number of friends and colleagues assisted the author, who is indebted to all of them. John Tennent photographed relevant specimens in institutional collections and facilitated 
several of the author's trips to the UK. Geoff Martin and Blanca Huertas (NHM) allowed the study of material in their care. Ullasa Kodandaramaiah, Kerala (India), sequenced certain material. Yusuke Takanami, Japan, provided photos of lectotypes held in MNHU and SMT. Jean Weiner, AM, improved the translation of Boisduval's description of $\mathrm{Ca}$ tochrysops cyta. Zsolt Bálint (Hungarian Natural History Museum, Hungary) and Oskar Brattström (University of Cambridge, UK) reviewed the manuscript.

\section{References}

Boisduval JBAD (1832) Faune entomologique de l'Océan Pacifique, avec l'illustration des insects nouveaux recueillis pendant le voyage. Première Partie: Lepidoptéres. In: d'Urville JD, Voyage découvertes de l'Astrolabe exécuté par ordre du Roi, Pendant les années 18261827-1828-1829, sous le commandement de M. J. Dumont d'Urville. J. Tastu, Paris, x + 267 pp., ill. Atlas: 5 pls.

Braby MF (2000) Butterflies of Australia. Their identification, biology and distribution. CSIRO Publishing, Canberra, 2 volumes, xxv, 976 pp.

Corbet AS, Pendlebury HM (1993) The butterflies of the Malay Peninsula. Malayan Nature Society, Kuala Lumpur; 4th edition, revised by J.N. Eliot, 597 pp.

D’Abrera B (1977) Butterflies of the Australian Region, edn. 2. Melbourne, 415 pp.

Domeny de Rienzi GL (1838) Océanie ou cinquième partie du monde: revue géographique et ethnographique de la Malaisie, de la Micronésie, de la Polynésie et de la Mélanésie, Volume 3. Firmin Didot Frères, editors, 632 pp.

Folmer O, Black MB, Hoch W, Lutz RA, Vrijehock RC (1994) DNA primers for amplification of mitochondrial c oxidase subunit I from diverse metazoan invertebrates. Molecular Marine Biology and Biotechnology 3: 294-299.

Fruhstorfer H (1915) Neue Lycaenidenformen aus dem Rijksmuseum in Leiden. Zoölogische Mededelingen, Leiden, 1: 141-148.

Fruhstorfer H (1916) Revision der Gattung Lampides auf Grund anatomischer Untersuchungen. Archiv für Naturgeschichte, Berlin, A81(6): 1-46.

Hirowatari T (1992) A generic classification of the tribe Polyommatini of the Oriental and Australian regions (Lepidoptera, Lycaenidae, Polyommatinae). Bulletin of the University of Osaka Prefecture, Osaka, B44, 102 pp.

Kunte K, Roy P, Kalesh S, Kodandaramaiah U (Eds) (2015) Butterflies of India, v. 2.20. Indian Foundation for Butterflies. http://www.ifoundbutterflies.org/

Müller CJ (2013) A remarkable new species of Candalides Hübner, 1819 (Lepidoptera, Lycaenidae) from the Bismarck Archipelago, Papua New Guinea. Nachrichten Entomologischen Vereins Apollo 34(1/2): 69-72.

Müller CJ (2014) Six new species of Philiris Röber, 1891 (Lepidoptera, Lycaenidae) from Papua New Guinea. ZooKeys 395: 33-55. doi: 10.3897/zookeys.395.7110

Müller CJ, Wills L (2013) The Delias Hübner, 1819 of the Bismarck Archipelago, Papua New Guinea, with description of a new species from New Britain Island (Lepidoptera, Pieridae). Nachrichten des Entomologischen Vereins Apollo 34(1/2): 17-26. 
Parsons MJ (1998) The butterflies of Papua New Guinea: their systematics and biology. Academic Press, San Diego, London, etc., xvi + 928 pp.

Rawlins A, Cassidy A, Müller CJ, Schröder S, Tennent WJ (2014) An illustrated and annotated checklist of Jamides Hübner, 1819, taxa occurring in the Indonesian provinces of North Maluku and Maluku (Lepidoptera: Lycaenidae). Nachrichten des Entomologischen Vereins Apollo, Frankfurt am Main, N.F. 35(1/2): 5-39.

Ribbe C (1899) Beitrage zur Lepidopteren-Fauna des Bismarck-und Salomo-Archipels in der Sud-See. Ibid 12: 219-260, pl. 4.

Riley ND, Corbet AS (1938) A revision of the Malayan species of Jamides Hübner (Lepidoptera: Lycaenidae). Transactions of the Entomological Society of London 87(5): 147-159. doi: 10.1111/j.1365-2311.1938.tb00732.x

Ronquist F, Huelsenbeck JP (2003) MrBayes 3: Bayesian phylogenetic inference under mixed models. Bioinformatics 19: 1572-1574. doi: 10.1093/bioinformatics/btg180

Rothschild W (1915) On Lepidoptera from the islands of Ceram (Seram), Buru, Bali and Misool. Novitates zoologicae, Tring 22: 105-144. doi: 10.5962/bhl.part.1914

Takanami Y (1989) On some type specimens of Lycaenidae from South East Asia (Lepidoptera). Tyô to Ga, Tokyo 40(1): 23-80.

Takanami Y (1994) Three new species of Lycaenidae (Lepidoptera) from Sulawesi. Tyô to Ga, Tokyo 45(1): 5-10.

Tamura K, Dudley J, Nei M, Kumar S (2006) Molecular Evolutionary Genetics Analysis (MEGA), Version 4.0 (Beta release).

Tennent WJ (2002) Butterflies of the Solomon Islands: systematics and biogeography. Storm Entomological Publications, England, xxiv, 413 pp.

Tennent WJ (2006) A checklist of the butterflies of Melanesia, Micronesia, Polynesia and some adjacent areas. Zootaxa 1178: 1-209.

Tennent WJ, Rawlins A (2012) A new Jamides Hubner, 1819 from the islands of North Maluku, Indonesia (Lepidoptera: Lycaenidae). Nachrichten des Entomologischen Vereins Apollo, Frankfurt am Main, N.F. 33(2/3): 139-141.

Toxopeus LJ (1930) De soort als functie van plaats en tijd. Getoetst aan de Lycaenidae van het Australaziatisch gebied. H. J. Paris, Amsterdam, 198 pp., pls.

Treadaway CG, Schröder HG (2012) Revised checklist of the butterflies of the Philippine Islands (Lepidoptera: Rhopalocera). Nachrichten des Entomologischen Vereins Apollo, Suppl. 20: 1-64.

Worcester JE (1817) A geographical dictionary, or universal gazetteer; ancient and modern, Volume 2. Published by Henry Whipple, Salem, 974 pp. 